\author{
Мартынова O.A., \\ кандидат философских наук, \\ доиент кафедры «Философия и сочиальные коммуникации», \\ Пензенский государственный университет, \\ Пенза, Россия
}

\begin{abstract}
Аннотация: статья посвящена взглядам К. Маркса и Ф. Энгельса на прошлое, настоящее и будущее России, её особенности и роль в мире. Выявляются основные проблемы истории России, которым уделяли внимание основоположники марксизма, систематизируются взгляды К. Маркса и Ф. Энгельса на современное положение России, на её место на мировой арене. Прослеживается степень объективности и фактическая обоснованность взглядов мыслителей.
\end{abstract}

Ключевые слова: марксизм, К. Маркс, Ф. Энгельс, Россия, философия истории, славяне, русская дипломатия, история России.

\title{
THE IMAGE OF RUSSIA IN THE WORKS OF K. MARX AND FR. ENGELS
}

Martynova O.A., Candidate of Philosophy, Associate professor of «Philosophy and social communication» department Penza State University, Penza, Russian Federation

\begin{abstract}
K. Marx and Fr. Engels on the past, present and future of Russia, its peculiarities and role in the world. Identifies major problems in the history of Russia, which paid attention to the founders of Marxism, sistematizirovat the views of K. Marx and FR. Engels on the current situation of Russia, its place on the world stage. Traces the degree of actual objectivity and the validity of the views of thinkers.
\end{abstract}

Key words: Marxism, Karl Marx, FR. Engels, Russia, philosophy of history, Slavs, Russian diplomacy, the history of Russia.

К. Маркс и Ф. Энгельс являются знаковыми фигурами в идеологии социализма. Их теория легла в основу социалистической революции в России. В России советского периода их труды активно изучались и послужили основой таких дисциплин, как научный коммунизм, диалектический материализм, исторический материализм; теория общественно-экономических формаций легла в основу советской исторической науки. Однако, по словам Н.А. Бердяева, революция в России произошла «во имя Маркса, но не по Марксу» [1]. Известно, что основоположники марксизма по разным причинам не видели Россию во главе социалистического движения. По их словам, «ненависть к русским была и продолжает ещё быть у немцев их первой революционной страстью... «беспощадная борьба не на жизнь, а на смерть» со славянством, предающим революцию, борьба на уничтожение и беспощадный терроризм не в интересах Германии, а в интересах революции» [2, с. 306]. Известны 
также их уничижительные высказывания о характере и способностях русских, например, об их «почти беспримерной способности к торговле в её низших формах, к использованию благоприятных обстоятельств и к неразрывно связанному с этим надувательству: недаром ведь ещё Пётр I говорил, что один русский справится с тремя евреями» [3, с. 539]. В свете подобных противоречий представляется интересной проблема отношения К. Маркса и Ф. Энгельса к России, их представления о её прошлом и будущем, об её позиции на мировой арене. Стоит отметить, что в данном вопросе К. Маркс и Ф. Энгельс были единомышленниками; сам Ф. Энгельс в работе «Внешняя политика русского царизма» отмечал, что, описывая негативное влияние русского царизма на развитие Европы, продолжает дело покойного друга.

Знания и мнение К. Маркса и Ф. Энгельса о России основывались на разнообразных источниках. Они были в курсе новостей о Крымской и русскотурецкой (1877-1878 гг.) войнах. Безусловно, они опирались на труды русских революционеров, с которыми полемизировали: М.А. Бакунина, П.Л. Лаврова, П.Н. Ткачева. Анализируя социально-экономическое положение России, Ф. Энгельс ссылался на «Сборник материалов об артелях в России» и работу Флеровского «Положение рабочего класса в России». Статьи для американской энциклопедии, посвящённые войне 1812 г., они писали, опираясь на мемуары Толя, которые считали лучшим изложением указанных событий. В.Н. Котов в лекциях «К. Маркс и Ф. Энгельс о России и русском народе» отмечает, что «среди прочитанных К. Марксом и Ф. Энгельсом книг имеются сочинения Карамзина, Соловьева, Костомарова, Беляева, Сергеевича и ряда других историков [4]. Правда, это не находит документального подтверждения; в «Хронологических заметках» К. Маркс излагает события европейской, а не русской истории. Таким образом, знания К. Маркса и Ф. Энгельса о России основаны на разнообразных источниках, но их вряд ли можно назвать глубокими и основательными.

Первое, что бросается в глаза при изучении взглядов основоположников марксизма на Россию - стремление подчеркнуть различия между русскими и европейцами. Так, говоря о русской истории, К. Маркс только на начальной её стадии - Киевской Руси - признаёт сходство с европейской. Империя Рюриковичей (название Киевская Русь он не употребляет) является, по его мнению, аналогом империи Карла Великого, а её стремительное расширение - «естественным следствием примитивной организации норманнских завоеваний... причем необходимость дальнейших завоеваний поддерживалась непрерывным притоком новых варяжских авантюристов» [5]. Из текста явствует, что К. Маркс считал данный период русской истории не этапом развития именно русского народа, а одним из частных случаев действий германских варваров, наводнивших в те времена Европу. Лучшим доказательством этой мысли философ считает то, что практически все киевские князья возводились на престол силой варяжского оружия (правда, он не приводит конкретных фактов). Влияние на этот процесс славян К. Маркс полностью отвергает, признавая славянским государством только Новгородскую республику. Когда верховная власть перешла от норманнов к славянам, 
империя Рюриковичей закономерно распалась, а монголо-татарское нашествие окончательно уничтожило её остатки. С тех пор пути России и Европы разошлись. Рассуждая о данном периоде русской истории, К. Маркс показывает в целом достоверное, но довольно поверхностное знание её событий: так, он пренебрегает даже таким известным фактом, что хана, установившего монголо-татарское иго на Руси, звали не Чингисхан, а Батый. Так или иначе, «колыбелью Московии было кровавое болото монгольского рабства, а не суровая слава эпохи норманнов» [5]. Пропасть между Россией и Европой не смогла заполнить деятельность Петра I, которую К. Маркс назвал стремлением «цивилизовать» Россию. Немецкие земли, по словам К. Маркса, «в изобилии снабдили его чиновниками, учителями и фельдфебелями, которые должны были вымуштровать русских, придав им тот внешний налёт цивилизации, который подготовил бы их к восприятию техники западных народов, не заражая их идеями последних» [5]. В своем стремлении показать непохожесть русских на европейцев основоположники марксизма заходят достаточно далеко. Так, в письме Ф. Энгельсу К. Маркс одобрительно отзывается о теории профессора Духинского о том, что «великороссы не славяне... настоящие московиты, то есть жители бывшего Великого княжества Московского, большей частью монголы или финны и т. д., как и расположенные дальше к востоку части России и её юго-восточные части... название Русь узурпировано московитами. Они не славяне и вообще не принадлежат к индогерманской расе, они intrus, которых требуется опять прогнать за Днепр» [6, с. 106]. Говоря об этой теории, К. Маркс берёт в кавычки слово «открытия», что показывает, что он не принимает её за непреложную истину. Однако далее он достаточно чётко обозначает своё мнение: «Я бы хотел, чтобы Духинский оказался прав и чтобы, по крайней мере, этот взгляд стал господствовать среди славян» [6, с. 107].

Говоря о России, основоположники марксизма отмечают и её экономическую отсталость. В работе «О социальном вопросе в России» Ф. Энгельс точно и обоснованно подмечает основные тенденции и проблемы развития пореформенной российской экономики: концентрацию земли в руках дворянства; поземельный налог, выплачиваемый крестьянами; огромную наценку на выкупаемую крестьянами землю; расцвет ростовщичества и финансового мошенничества; расстройство финансовой и налоговой системы; коррупцию; разрушение общины на фоне усиленных попыток государства сохранить её; малограмотность рабочих, способствующую эксплуатации их труда; беспорядок в сельском хозяйстве, нехватку земли у крестьян и рабочей силы у помещиков. На основании приведённых данных мыслитель делает неутешительный, но справедливый вывод: «нет другой такой страны, в которой при всей первобытной дикости буржуазного общества был бы так развит капиталистический паразитизм, как именно в России, где вся страна, вся народная масса придавлена и опутана его сетями» $[3$, с. 540$]$.

Наряду с экономической отсталостью России К. Маркс и Ф. Энгельс отмечают её военную слабость. По словам Ф. Энгельса, Россия практически 
неприступна в обороне в силу своей обширной территории, сурового климата, бездорожья, отсутствия центра, захват которого обозначил бы исход войны, и стойкого, пассивного населения; однако, когда речь заходит о нападении, все эти достоинства превращаются в недостатки: обширная территория затрудняет передвижение и снабжение армии, пассивность населения оборачивается безынициативностью и инертностью, отсутствие центра порождает беспорядки. Подобные рассуждения, безусловно, не лишены логики и основаны на знании истории войн, которые вела Россия, однако Ф. Энгельс делает в них существенные фактические ошибки. Так, он полагает, что Россия занимает территорию «с исключительно однородным в расовом отношении населением» [7, с. 16]. Трудно сказать, по каким причинам мыслитель игнорировал многонациональность населения страны: он просто не владел подобной информацией или считал её несущественной в данном вопросе. Кроме того, Ф. Энгельс проявляет некоторую ограниченность, говоря, что Россия уязвима только со стороны Европы.

Основоположникам марксизма присуще желание умалить военные успехи России и значение её побед. Так, излагая историю освобождения России от монголо-татарского ига, К. Маркс ни словом не упоминает о Куликовской битве. По его словам, «когда татарское чудовище наконец испустило дух, Иван явился к его смертному одру скорее как врач, предсказавший смерть и использовавший её в своих интересах, чем как воин, нанёсший смертельный удар» [5]. Участие России в войнах с Наполеоном классики марксизма считают средством реализации захватнических планов России, в частности, по разделу Германии. Остается без внимания тот факт, что действия русской армии (в частности, самоубийственный переход армии под предводительством Суворова через Альпы) спасали Австрию и Пруссию от полного разгрома и завоевания и осуществлялись как раз в их интересах. Свое видение антинаполеоновских войн Ф. Энгельс описывает следующим образом: «Её (Россию) могут устроить только такие войны, когда союзники России должны нести основное бремя, подвергать свою территорию, превращённую в театр военных действий, опустошениям и выставлять наибольшую массу бойцов, в то время как русские войска выполняют роль резервов, которые щадят в большинстве боёв, но на долю которых во всех крупных сражениях выпадает связанная со сравнительно небольшими жертвами честь решать окончательный исход дела; так это и было в войне 18131815 годов» [7, с. 16-17]. Даже план кампании 1812 г. по стратегическому отступлению русской армии разработал, по его словам, прусский генерал Фуль, а М.Б. Барклай-де-Толли был единственным генералом, не поддавшимся бесполезной и глупой панике и предотвратившим попытки спасти Москву. Здесь налицо откровенное пренебрежение историческими фактами, что выглядит странным с учётом того, что К. Маркс и Ф. Энгельс написали серию статей о данной войне для американской энциклопедии, ссылаясь на мемуары К.Ф. Толя, воевавшего на стороне России. Неприязнь к России оказывается настолько велика, что отношение к её участию в антинаполеоновских войнах выражается в весьма оскорбительной форме: «русские и поныне ещё по- 
хваляются тем, что они своими бесчисленными войсками решили падение Наполеона» [2, с. 300].

Будучи невысокого мнения о военной мощи России, русскую дипломатию К. Маркс и Ф. Энгельс считали её сильнейшей стороной, а внешнеполитические успехи - важнейшим достижением на мировой арене. Внешнеполитическая стратегия России (допетровскую Россию К. Маркс называет Московией) выросла «в ужасной и гнусной школе монгольского рабства» [5], что диктовало определённые методы дипломатии. Московские князья, основатели нового государства Иван Калита и Иван III переняли у монголотатар тактику подкупа, притворства, использования интересов одних групп против других. Они втирались в доверие к татарским ханам, настраивали их против своих противников, использовали противостояние Золотой Орды с Крымским ханством и новгородского боярства с купечеством и бедным населением, амбиции римского папы - в целях укрепления светской власти над православной церковью. Князь «должен был превратить в систему все уловки самого низкого рабства и применять эту систему с терпеливым упорством раба. Открытая сила сама могла входить в систему интриг, подкупа и скрытой узурпации лишь в качестве интриги. Он не мог ударить, не дав предварительно яда. Цель у него была одна, а пути её достижения многочисленны. Вторгаться, используя обманным путём враждебную силу, ослаблять эту силу именно этим использованием и, в конце концов, ниспровергнуть её с помощью средств, созданных ею же самой» [5]. Далее русские цари активно использовали наследие московских князей. В работе «Внешняя политика русского царизма» Ф. Энгельс со смесью неприязни и восхищения подробно описывает тончайшую дипломатическую игру, которую вела русская дипломатия в эпоху Екатерины II и Александра I (правда, не забыв подчеркнуть немецкое происхождение всех великих дипломатов). Россия, по его словам, замечательно играла на противоречиях между крупнейшими европейскими державами - Англией, Францией и Австрией. Она могла безнаказанно вмешиваться во внутренние дела всех стран под предлогом защиты порядка и традиций (если играла на руку консерваторам) или просвещения (если нужно было подружиться с либералами). Именно Россия во время американской войны за независимость впервые сформулировала принцип вооружённого нейтралитета, впоследствии активно используемый дипломатами всех стран (на тот момент эта позиция ослабила морское превосходство Англии). Она активно использовала националистическую и религиозную риторику для расширения своего влияния в Османской империи: вторгалась на её территорию под предлогом защиты славян и православной церкви, провоцировала восстания покорённых народов, которые, по убеждению Ф. Энгельса, жили совсем не плохо. При этом Россия не боялась поражений, так как Турция была заведомо слабым соперником. Путём подкупов и дипломатических интриг Россия долгое время поддерживала раздробленность Германии и держала в зависимости Пруссию. Возможно, это и является одной из причин неприязни К. Маркса и Ф. Энгельса к России. Именно Россия, по мнению Ф. Энгельса, стёрла Польшу с карты мира, отдав её часть 
Австрии и Пруссии. Этим она убила двух зайцев: ликвидировала беспокойного соседа и надолго подчинила себе Австрию и Пруссию. «Кусок Польши был той костью, которую царица бросила Пруссии, чтобы заставить её смирно сидеть целое столетие на русской цепи» [7, с. 23]. Таким образом, вину за уничтожение Польши мыслитель целиком сваливает на Россию, забыв упомянуть о заинтересованности Пруссии и Австрии.

Россия, по словам мыслителей, постоянно вынашивает захватнические планы. Целью московских князей было подчинение русских земель, делом жизни Петра I - укрепление на Балтийском побережье (именно поэтому, по мнению К. Маркса, он перенёс столицу на вновь завоёванные земли), Екатерина II и её наследники стремятся к захвату Константинополя, чтобы контролировать Чёрное и часть Средиземного моря. К этому мыслители прибавляют завоевательные войны на Кавказе. Наряду с расширением экономического влияния они видят у подобной политики ещё одну цель. Для поддержания царской власти и власти дворянства России необходимы постоянные внешнеполитические успехи, которые создают иллюзию сильного государства и отвлекают народ от внутренних проблем (тем самым освобождая власть от необходимости их решать). Подобная тенденция характерна для всех стран, но К. Маркс и Ф. Энгельс показывают её именно на примере России. В критическом запале основоположники марксизма рассматривают факты несколько односторонне. Так, они сильно преувеличивают слухи о благоденствии сербских крестьян под гнётом турок; умалчивают об опасности, которая грозила России со стороны Польши и Литвы (эти страны к XVIII веку уже не могли всерьёз угрожать России, но всё же были постоянным источником беспорядков); не сообщают подробности жизни кавказских народов под властью Персии и игнорируют тот факт, что многие из них, например, Грузия, сами просили Россию о помощи (возможно, они просто не владели этой информацией).

Но всё же основной причиной отрицательного отношения К. Маркса и Фр. Энгельса к Российской империи является её непримиримая ненависть к революции и прогрессивным изменениям в обществе. Ненависть эта вытекает как из самой природы деспотической власти, так и из низкого уровня развития общества. В России борьба деспотизма против свободы имеет длительную историю. Ещё Иван III, по словам К. Маркса, понял, что непременное условия существования единой сильной Московии - уничтожение русских вольностей, и бросил силы на борьбу против остатков республиканской власти на окраинах: в Новгороде, Польше, казачьей республике (не совсем понятно, что имел в виду К. Маркс, говоря о ней). Поэтому он «сорвал цепи, в которые монголы заковали Московию, только для того, чтобы опутать ими русские республики» [5]. Далее Россия успешно извлекала выгоду из европейских революций: благодаря Великой французской революции она смогла подчинить своему влиянию Австрию и Пруссию и уничтожить Польшу (сопротивление поляков отвлекло Россию от Франции и помогло революционерам). Борьба против Наполеона, в которой Россия играла решающую роль, также была борьбой против революционной Франции; после 
победы Россия заручилась поддержкой восстановленной монархии. По этой же схеме Россия приобрела союзников и расширила сферу своего влияния после революций 1848 г. Заключив с Пруссией и Австрией Священный Союз, Россия стала оплотом реакции в Европе. Подавляя революции в Европе, Россия усиливает своё влияние на её правительства, ликвидирует потенциальную опасность для себя, а также отвлекает собственный народ от внутренних проблем. Если учесть, что К. Маркс и Ф. Энгельс считали социалистическую революцию закономерным итогом развития Европы, становится понятно, почему они считали, что Россия своим вмешательством нарушает естественный ход развития европейских стран и для победы рабочая партия должна бороться не на жизнь, а на смерть с русским царизмом.

Говоря о видении России К. Марксом и Фр. Энгельсом, необходимо отметить ещё одну существенную деталь: противопоставление правительства и народа. В любой стране, в том числе и в России, правительство очень редко отстаивает народные интересы. Монголо-татарское иго способствовало усилению московских князей, но иссушило душу народа. Пётр I «перенесением столицы порвал те естественные узы, которые связывали систему захватов прежних московитских царей с естественными способностями и стремлениями великой русской расы. Поместив свою столицу на берегу моря, он бросил открытый вызов антиморским инстинктам этой расы и низвел её до положения просто массы своего политического механизма» [5]. Дипломатическими играми XVIII - XIX вв., поднявшими Россию до небывалого могущества, занимались иностранцы на русской службе: Поццо-ди-Борго, Ливен, К.В. Нессельроде, А.Х. Бенкендорф, Медем, Мейендорф и др. под руководством немки Екатерины II и её наследников. Русский народ, по мнению основоположников марксизма, вынослив, храбр, стоек, но пассивен, поглощён частными интересами. Благодаря этим свойствам народа русская армия непобедима в том случае, когда исход боя решают сомкнутые массы. Однако умственный застой народа и низкий уровень развития общества приводит к тому, что народ не имеет собственной воли и всецело доверяет легендам, которые распространяет власть. «В глазах вульгарно-патриотической публики слава побед, следующие одно за другим завоевания, могущество и внешний блеск царизма с избытком перевешивают все его грехи, весь деспотизм, все несправедливости и произвол» [7, с. 15]. Это приводило к тому, что русский народ, даже сопротивляясь несправедливости системы, никогда не восставал против царя. Подобная пассивность народа - необходимое условие успешной внешней политики, основанной на завоеваниях и подавлении прогресса.

Однако впоследствии К. Маркс и Ф. Энгельс пришли к выводу, что после поражения России в Крымской войне мировоззрение народа изменилось. Народ начал критически относиться к власти, интеллигенция способствует распространению революционных мыслей, промышленное развитие становится все более важным для внешнеполитических успехов. Поэтому в России конца XIX века возможна революция: в предисловии к русскому 
изданию «Манифеста коммунистической партии» К. Маркс и Ф. Энгельс называют Россию передовым отрядом революционного движения в Европе. Мыслители не отрицают, что революция в России в силу особенностей развития страны пройдёт иначе, чем могла бы пройти в Европе: из-за того, что большая часть земли в России находится в общинном владении, русская революция будет по преимуществу крестьянской, а община станет ячейкой нового общества. Русская революция станет сигналом для революций в других европейских странах.

Социалистическая революция не только преобразует Россию, но и существенно изменит расстановку сил в Европе. Ф. Энгельс в 1890 г. обозначает существование в Европе двух военно-политических союзов: России с Францией и Германии с Австрией и Италией. Союз Германии, Австрии и Италии существует, по его словам, исключительно под влиянием «русской угрозы» на Балканах и Средиземном море. В случае ликвидации царского режима в России эта угроза исчезнет, т.к. Россия переключится на внутренние проблемы, агрессивная Германия, оставшись в одиночестве, не решится развязать войну. Европейские страны будут строить отношения на новой основе партнёрства и прогресса. Подобные рассуждения нельзя безусловно принять на веру. Ф. Энгельс перекладывает на Россию всю ответственность за предстоящую мировую войну и обходит вниманием стремление европейских стран к переделу колоний за пределами Европы, из-за которого война всё равно стала бы неизбежна.

Таким образом, во взглядах К. Маркса и Ф. Энгельса прослеживается двойственность в отношении России. С одной стороны, они подчёркивают её несходство с Европой и отрицательную роль в развитии Запада, с другой стороны, их критика направлена на правительство, а не на русский народ. Кроме того, ход русской истории заставил основоположников марксизма пересмотреть своё отношение к России и признать её возможную роль в историческом прогрессе.

\section{Источники и литература:}

1. Бердяев Н.А. Истоки и смысл русского коммунизма [Электронный ресурс]. http://lib.ru/HRISTIAN/BERDQEW/duhi.txt

2. Энгельс Ф. Демократический панславизм // Маркс К. и Энгельс Ф. Соч. Изд. 2. - Т. 6. - М.: Политиздат, 1962.

3. Маркс К. О социальном вопросе в России // Маркс К. и Энгельс Ф. Соч. Изд. 2. - Т. 18. - М.: Политиздат, 1962.

4. Котов В.Н. К.Маркс и Ф.Энгельс о России и русском народе. М.: Знание, 1953 [Электронный ресурс]. - http://www.biografia.ru/arhiv/orossii02.html

5. Маркс К. Разоблачения дипломатической истории XVIII века [Электронный ресурс]. http://www.gumer.info/bibliotek_Buks/History/diplomat_history/index.php

6. К. Маркс - Ф. Энгельсу в Манчестер // Маркс К. и Энгельс Ф. Соч. Изд. 2. - Т. 31. М.: Политиздат, 1962.

7. Энгельс Ф. Внешняя политика русского царизма // Маркс К. и Энгельс Ф. Соч. Изд. 2. - Т. 22. - М.: Политиздат, 1962. 


\begin{abstract}
Referenses
1. Berdyaev N.A. Istoki i smysl russkogo kommunizma [EHlektronnyj resurs]. http://lib.ru/HRISTIAN/BERDQEW/duhi.txt

2. EHngel's F. Demokraticheskij panslavizm // Marks K. i EHngel's F. Soch. Izd. 2. - T. 6. M.: Politizdat, 1962.

3. Marks K. O sotsial'nom voprose v Rossii // Marks K. i EHngel's F. Soch. Izd. 2. - T. 18. M.: Politizdat, 1962.

4. Kotov V.N. K.Marks i F.EHngel's o Rossii i russkom narode. M.: Znanie, 1953 [EHlektronnyj resurs]. - http://www.biografia.ru/arhiv/orossii02.html 5. Marks K. Razoblacheniya diplomaticheskoj istorii XVIII veka [EHlektronnyj resurs]. http://www.gumer.info/bibliotek_Buks/History/diplomat_history/index.php

6. K. Marks - F. EHngel'su v Manchester // Marks K. i EHngel's F. Soch. Izd. 2. - T. 31. - M.: Politizdat, 1962.

7. EHngel's F. Vneshnyaya politika russkogo tsarizma // Marks K. i EHngel's F. Soch. Izd. 2. T. 22. - M.: Politizdat, 1962.
\end{abstract}

\title{
УДК 323.2+323.4+321.01 DOI: 10.24045/conf.2017.1.19 ТЕОРИИ СОЦИАЛЬНОЙ РЕВОЛЮЦИИ ХХ ВЕКА В ЗАПАДНОЙ
ЕВРОПЕ И США: ОБЗОР ОСНОВНЫХ НАПРАВЛЕНИЙ
}

Сиушкин А.Е.,
кандидат социологических наук,
доцент кафедры «Теория государства и права и политология»,
Пензенский государственный университет,
Пенза, Россия

Милаева O.B., кандидат исторических наук, дочент кафедрь «Философия и соичиальнье коммуникациии», Пензенский государственный университет,

Пенза, Россия

Аннотация. Статья посвящена обзору основных концепџий революции в науке ХХ века. Авторы акцентируют внимание на теоретизации причин революцчии в ходе развития научной теории на протяжении последнего столетия. В задачу включается рассмотрение предметного комплекса основных подходов к изучению револючии, основных направлений проводимых исследований. В статье рассматриваются сочиально-психологические концепџии, неомарксизм, политические конщепичии, системный подход, макросочииология и структурализм, методы математического моделирования сочиальных конфликтов.

Ключевые слова: теория револючฺии, причины револющии, револющия, социиальный конфликт, классовая борьба. 